\title{
HIGHLY EVOLVED TIN GRANITES: A CANADIAN EXAMPLE
}

\section{TIMOTHY LIVERTON}

\begin{abstract}
RESUMO GRANITOS ESTANÍFEROS ALTAMENTE EVOLUÍDOS: O EXEMPLO CANADENSE A pequena suite de granitos Seagull-Thirtymile, constituída de biotita granitos leucocráticos, e os depósitos de estanho associados têm idade cretácica média e estão situados no centro-sul do território de Yukon, no Canadá. Eles são intrusivos nos terrenos metassedimentares Dorsey, que são, parautóctones. Este tipo de mica granito leucocrático é raro nesta região, predominantemente constituída de batólitos cálcio alcalinos pertencentes ao Cinturão Plutônico Omineca. Os granitos Seagull-Thirtymile têm semelhanças químicas com as intrusões tardi-orogênicas e alcalinas e possuem, como componentes mais jovens, um stock alasquítico e volumes menores de álcali-feldspato granito muito fracionado, com altos teores de $\mathrm{F}$ e $\mathrm{Li}$ e $\mathrm{Rb} / \mathrm{Sr}>3000$. Dois mecanismos podem ser considerados como responsáveis pela geração de rochas tão evoluídas: enriquecimento em quartzo num sistema com baixo teor de F (como no stock alasquítico) e enriquecimento em albita sob condições de alto teor de F em apófises situadas acima do batolito. As micas ferro-litiníferas deste grupo de granitos são semelhantes às micas da região da Cornuália, sendo entretanto consideradas primárias, não constituindo uma série muscovita-zinnwaldita ou fengita-zinnwaldita. As micas dos granitos menos evoluídos são mais ricas em Fe que as micas da Cornuália e suas composições são muito, afins com as as dos granitos tipo quase-A. A fugacidade relativa dos halogêneos existentes no fluido aquoso dentro do magma indica que um fluido mais rico em $\mathrm{Cl}$ do que $\mathrm{F}$ foi produzido no sistema hidrotermal. Este resultado mostra que o sistema foi aberto, permitindo a concentração de met als no fluido hidrotermal. A formação de granitos tipo A imediatamente após à época do pico de plutonismo cordilheirano não é explicada pelos modelos tectônicos existentes.
\end{abstract}

Palavras-chaves:Canadá, granitos, estaníferos Yukon, geoquímica, química mineral

\begin{abstract}
The small Seagull-Thirtymile suite of mid Cretaceous tin-related granites is found in the south-central Yukon Territory of Canada, where they intrude the displaced, and possibly accreted, Dorsey terrane of uncertain affinity to the continent. These one-mica generally leucocratic granites are atypical of the calc-alkaline batholiths found in the Omineca plutonic belt of the Cordillera. They have a major- and trace-element chemical signature similar to post-orogenic and alkaline granitoids and contain small volumes of extremely fractionated, F-Li-rich leucogranites (e.g. with $\mathrm{Rb} / \mathrm{Sr}$ ratios $>3000$ ) as their youngest components, as well as an alaskite lithofacies in the STQ stock. Two possible fractionation mechanisms are indicated for the evolved lithofacies: enrichment in quartz in low-F apophyses above the main batholith and enrichment in albite, where high-F conditions prevailed. Fe-Li micas from the suite are similar to those reported for Cornubia and are considered to be primary, with no indication of either the muscovite-zinnwaldite or phengite-zinnwaldite substitution series. Those micas from the less-evolved granite facies have a more Fe-rich composition than the Cornubian examples and their composition may be diagnostic of these 'quasi-A-type' granites. Calculation of relative halogen fugacities in aqueous (magmatic) fluid existing with magma indicate that a Cl-rich (relative to F) hydrothermal system evolved, which is consistent with a shallow, periodically open system that would have allowed 'scavenging' and transport of ore met als from the granite. Existence of A-type granites in the Cordillera immediately following peak plutonism, without sufficient time gap to be able to label them truly "Post-Orogenic" is unexplained by the current tectonic model that has not addressed the possibility of either a period of crustal extension beginning at $\approx 100 \mathrm{Ma}$ or intrusion of basic magma perhaps to middle crustal levels.
\end{abstract}

Keywords:Canada, Yukon Tin-granites, geochemistry, mineral chemistry

INTRODUCTION Occurrences of tin are known throughout the , Micas in these granites range from siderophyllite to lepidolite. North American Cordillera, but are sparsely distributed. In the Yukon Complete analyses of mica separates has allowed relative halogen two suites of tin-related granitoid plutons are found on opposite sides fugacities to be calculated for the magmas and these results are consisof the Tintina-Rocky Mountain fault system that since the early tent with evolution of a shallow 'open-system', where early release of Tertiary has produced approximately $450 \mathrm{~km}$ of dextral strike-slip volatiles into a hydrothermal phase enhanced ore met al concentration movement (Fig. 1). These are the Tombstone suite (Mortensen 1996) and transport into the aureole.

and Seagull-Thirtymile suite. The latter granites (Liverton 1992; THE INTRUSIONS From SE to NW the Cretaceous intrusions Liverton \& Alderton 1994) are on the western side of the Tintina fault are: Seagull $(14 \mathrm{x} 44 \mathrm{~km}$ outcrop$), H a k e ~(17 \times 31 \mathrm{~km})$, Ork $(<1 \mathrm{~km} 2$ system and intrude an imbricated sequence of siliciclastic and minor exposed in a deep valley) and Thirtymile Stock (4.5x6 km). Other carbonate sediments of the displaced Dorsey terrane. These sediments gabbro to granodiorite intrusions in the Thirtymile Range are chemihave much similarity to North American continental stratigraphy, but cally and mineralogically distinct from the tin-related granites and are the origin of the terrane remains equivocal.

The Mid Cretaceous Seagull-Thirtymile plutons of the south central Yukon follow a narrow trend parallel to the fabric of the Cordillera over a $110 \mathrm{~km}$ length. Many minor occurrences and one significant deposit (the "JC": Layne \& Spooner 1986, 1991) of tin in skarns and quartz stockworks are known from the aureoles of these granites. This study has concentrated on the stocks of the Thirtymile Range and associated mineralization, but a reconnaissance sampling of the Hake and Seagull batholiths to the SE was performed to enable geochemical comparisons to be made throughout the known tin granites of the southern Yukon. mid Jurassic (Liverton 1992; Gordey \& Stephens 1994).

The Seagull Batholith The reconnaissance work of this study indicates that there are two facies of equigranular granite in this body, the eastern end of the body containing a more fractionated facies than the NW. Megacrystic lithofacies are reported by Mato et al. (1983), but the central portion of the batholith was not accessible to this study. A biotite-only ferromagnesian content predominates and these micas are often distinctly reddish, indicating relatively reduced (ilmenitetype) magma.

STQ Stock On the north side of the Seagull batholith a quartz-vein

The Seagull-Thirtymile granite suite is a highly evolved, F-rich, stockwork in sediments (the STQ prospect) was investigated by dialeucocratic group of undeformed plutons that were intruded at the end mond drilling in the early 1980s. An alaskite stock was intersected in of peak plutonism/metamorphism in the northern Omineca Belt of the the drillholes.

Cordillera. Their chemistry indicates an affinity with 'A-type' granites, yet they are neither peralkaline nor rift-related. The timing of emplacement is at the most 5Ma after intrusion of the huge Cassiar batholith, which is immediately to the east. There is no time gap which might
allow these to be considered 'post-orogenic collisional' granites in the usual sense, where such plutons might be at least 20 Ma younger than facies show partial mantling of orthoclase perthite phenocrysts by
the related continent collision event. The small-volume, extremely plagiolase. Known mineralization peripheral to this intrusion is skarn

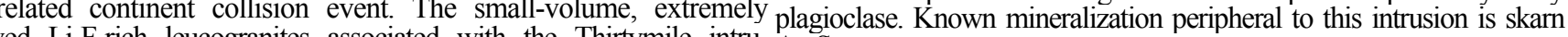
列 sions (and possibly the stocks adjacent to the JC property, which were not accessible to this study) probably represent the end-product of The Ork Stock Contains only Li-mica leucogranite. Texture of fractionation of magma in an underlying continuous batholith (Liver- this lithofacies is dominated by equant subhedral quartz $<4 \mathrm{~mm}$ grain ton \& Alderton 1994).

* Universidade de Brasília, Instituto de Geociências, Asa Norte, Brasília, DF 70910-900, Brasil, e-mail: timliv@guarany.cpd.unb.br 

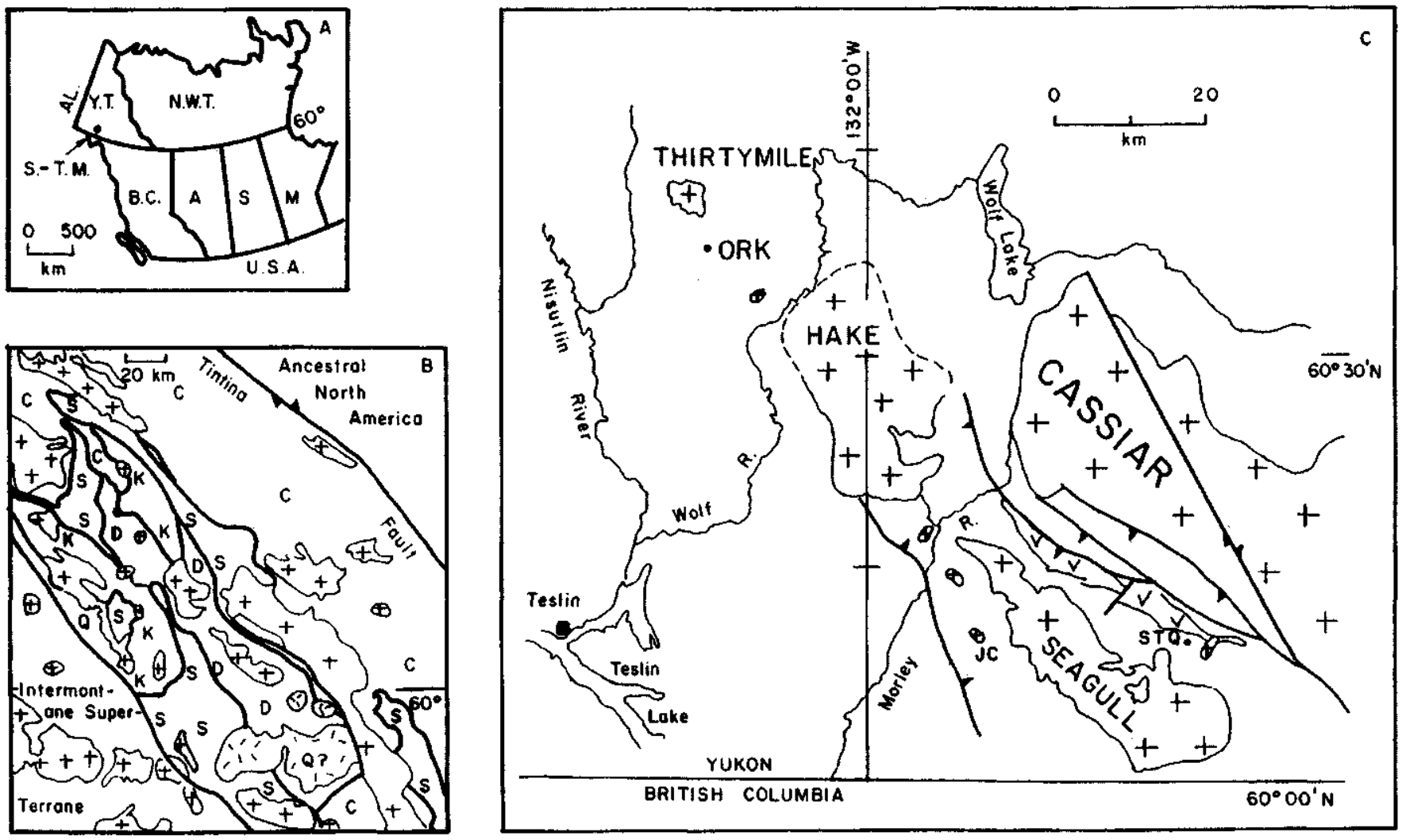

Figure 1 - Location of the Seagull-Thirtymile granites in the northern Cordillera, la shows Western Canadian Provinces. Ib shows the terranes of the Omineca belt in the southern Yukon, which includes displaced terranes east of the Teslin Fault as well as part of the autocthonous continental margin east of the Tintina Fault. $C=$ Cassiar; $S=$ Slide Mountain; $K=$ Kootenay; $Q=$ Quesnellia; $D=$ Dorsey. $1 c$ shows the Cretaceous granitic plutons of the Seagull-Thirtymile suite (crosses) and the (?) Jurassic Ram Stock. Tin prospects STQ and JC are also shown. Thrust (triangle ornament) and strike-slip faults are shown.

size with finer euhedral albite, subordinate orthoclase, topaz, zinnwaldite and fluorite.

The Thirtymile Stock Contains the greatest chemical and mineralogical variety of the whole suite. The bulk of the stock is composed of two biotite granite facies referred to as 'megacrystic' and 'equigranular' as convenient names. The former shows some orthoclase phenocrysts up to $15 \mathrm{~mm}$ long and is often pink with partially mantled orthoclase phenocrysts, whilst the latter is predominantly finer grained and may be white. No amphibole occurs in these two facies. The least chemically evolved facies is a porphyry, which is found as a series of bodies over a roughly linear trend within the other two biotite granites, crossing the entire stock and also as occasional enclaves from decimetre to several metres scale in both biotite facies. It is interpreted as a disaggregated synplutonic dyke. The central exposure of this body shows a variation from a mesoscopically fine-grained seriate-textured granodioritic rock at the east end to the same lithology crowded with enclaves (on metre scale) of granite porphyry $600 \mathrm{~m}$ to the west. Schlieren and 'dents de cheval' feldspar megacrysts crossing the contact of the enclaves indicate that the enclaves were likely the product of mingling of a cumulate with granodioritic magma (the two textural variants are only $2.5 \%$ different in silica content). This lithofacies is the only one of the whole suite to display hornblende. Exposures on the west side of the stock show orthoclase phenocrysts (with rounded ends, i.e. likely somewhat resorbed) up to $30 \mathrm{~mm}$ long with plagioclase mantles. The SE corner of the stock has a small extent of Li-mica leucogranite (similar $\mathrm{R}_{0}$ that of the Ork stock) exposed, associated with two sills in the metasediments above. At the topographic high in the upper sill ( $<6 m$ thick) an estimated concentration of about $20 \%$ of topaz is seen as irregular grains and veinlets. Small dykes of leucogranite are also seen at various localities surrounding the pluton. Accessory minerals in the Thirtymile biotite-bearing lithofacies are apatite, monazite and zircon.

GEOCHEMISTRY Analytical Methods Analysis was performed at Royal Holloway, University of London, for rocks using
X-ray fluorescence on glass disks fused with lithium metaborate flux for major elements and pressed powder disks for trace elements. Analysis of mica concentrates prepared by magnetic separation and final hand-picking was by inductively-coupled plasma emission spectroscopy following lithium metaborate fusion, $\mathrm{Fe}^{2+}$ by the Wilson titration method, with $\mathrm{F}$ determination following $\mathrm{Na}_{2} \mathrm{CO}_{3}$ fusion by the method of Hall \& Walsh (1969), Cl by ion-selective electrode, Rb by atomic absorption spectroscopy and $\mathrm{H}_{2} \mathrm{O}$ by gravimetry.

Chemical Trends The range of chemical compositions in the suite is indicated in the examples shown in Table 1.

Harker diagrams (Fig. 3A) for the biotite granites show approximately linear trends for both Thirtymile and Ork stocks (containing the greatest compositional range of the suite) and the batholiths. The Li-mica leucogranites of the Thirtymile and Ork stocks, however, plot as a reverse trend from the most evolved Equigranular specimens, with the leucogranites of higher $\mathrm{Rb} / \mathrm{Sr}$ ratio plotting to the left (lower silica). When a function such as the Thornton-Tuttle differentiation index is used all these granites define a linear trend. This is considered to be function of the F-rich system in the most evolved facies. If CIPW normative quartz-albite-anorthite components are plotted on a ternary diagram (Fig. 4) two possible trends for the whole suite are seen: a trend of quartz enrichment (towards the composition of the STQ alaskite) and a trend towards albite in the F-rich system of the Li-mica leucogranites. This latter trend compares well with experimental data of Manning (1982) for a F-bearing granite system in a shallow environment (pressure $=100 \mathrm{MPa}$ ).

Strontium Isotopes Initial Sr-isotopic ratios for the Thirtymile stock were determined for whole-rock specimens (Liverton 1992) and ${ }^{87} \mathrm{Sr}^{8(\mathrm{~S}} \mathrm{Sr}_{1}$ ranges from 0.7060 for Thirtymile Porphyry to $0.7074 \pm 0.0011$ (2?) for the Megacrystic lithofacies. This range of values indicates a largely 'I-type' source for the granite magmas with some crustal component. A cooling age of $100 \mathrm{Ma}$ was deduced.

Trace Element Contents And Comparison With Tectonic Discrimination Diagrams A spidergram (Fig. 5) demonstrates 
A
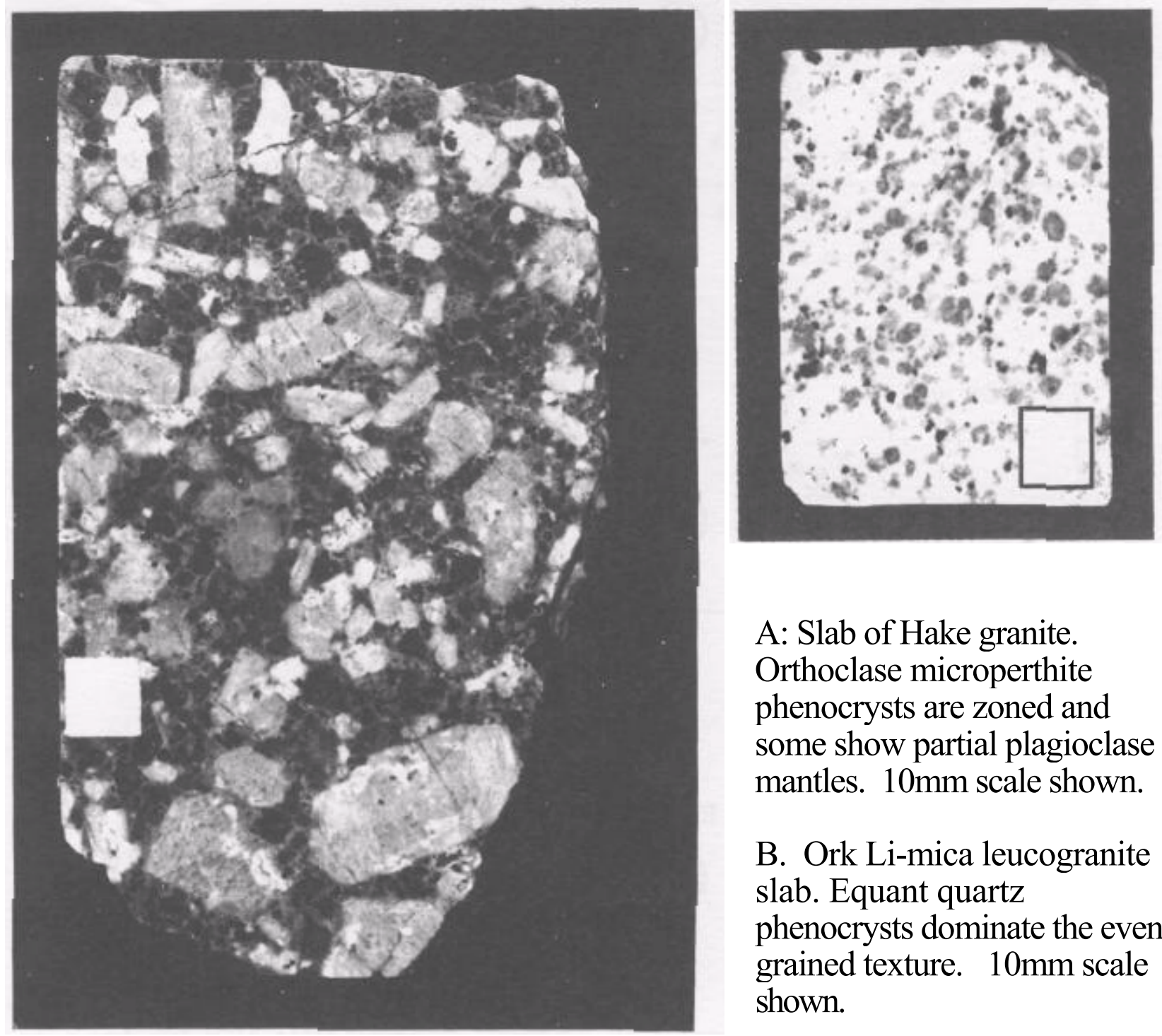

A: Slab of Hake granite. Orthoclase microperthite phenocrysts are zoned and some show partial plagioclase mantles. $10 \mathrm{~mm}$ scale shown.

\section{B. Ork Li-mica leucogranite slab. Equant quartz phenocrysts dominate the even- grained texture. $10 \mathrm{~mm}$ scale shown.}

Figure 2 - Photographs of granites from the Hake balholhh and Ork stock.

the similarity of the Thirtymile granite to the 'mildly alkaline' HHP (High Heat Production) granites, with deep negative $\mathrm{Ba}$ and $\mathrm{Sr}$ anomalies in the evolved lithofacies and a general lack of negative $\mathrm{Nb}$ anomalies (c.f. Plant et al. 1985). Other trace clement diagrams (Figs. 6 and 7) demonstrate the highly fractionated nature of these granites e.g. minimum $\mathrm{Rb} / \mathrm{Sr}$ value for the suite is 1.8 , which is greater than many granites (c.f. values for SE Asian tin belt in Cobbing et al. 1992, or those of the various papers on the North American Cordillera in Anderson 1990). Liverton \& Alderton (1994) considered that the elevated $\mathrm{Ga} / \mathrm{Al}$ ratios of the Seagull and Li-mica Icucogranites were the result of fractionation of $\mathrm{Ga}$ in the very evolved lithofacies (see Fig. 3D). It was postulated that in halogen-rich systems a process of 'ultrafractionation' would scavenge incompatible ore met als from the residual melt fractions of the pluton sufficient to produce a depletion of the element relative to less fractionated facics (Fig. 3E). Copper is erratically enriched in some of the lithofacies (Fig. 3F).

Although there has been strong polarization in recent discussion (the Granite Network of the Internet) regarding the validity of 'tectonic' discrimination diagrams, not every granite petrologist is willing to discard these tools as being useless. Such diagrams may not yield clear separation of every granite type, but they at least do indicate differences! The granites of this work demonstrate textural and chemical similarities with many A-type granites (if ' $\mathrm{A}$ ' is interpreted in the 'alkaline' sense). They are met aluminous to peraluminous, but not perakaline. Their alkali contents fall largely within the field defined for 'Post-Orogenic' granites by Maniar \& Piccoli (1989) (Fig. 8). On trace element diagrams these granites often fall in the 'within-plate' field, but also overlap the 'fractionated' field of Whalen- \& Sylvestertype diagrams (Fig. 7C and E) or 'continent-collision' field of Harris et al. (1986) and perhaps are best described as 'subalkaline' in the French sense (see Barbarin 1990: p. 233) where this denotes 'nearly alkaline' and transitional between his $\mathrm{H}_{\mathrm{LO}}$ ('hybrid late-orogenic') and A-types.

Micas CHEMISTRY Micas in the Seagull-Thirtymile granites vary from siderophyllite through zinwaldite to lepidolite according to the modified classification of Tindle \& Webb (1990). Textural evidence indicates that they are primary, except for the Seagull batholith where occasional Li-mica alteration rims on biotite, often accompanied by adjacent tourmaline and fluorite, are seen.

For a few micas from the Li-mica and cquigranular lithofacies used for Fig. 9 (those shown as circles) some of combined water, Rb and fluorine contents for structural formula calculation were estimated using the following empirical relationships:

$\mathrm{H}_{2} \mathrm{O}=-0.1291\left(\mathrm{SiO}_{2}\right)+6.6682$

$\mathrm{F}=1.4853\left(\mathrm{Li}_{2} \mathrm{O}\right)+1.0646$

$\mathrm{Rb}_{2} \mathrm{O}=0.3601\left(\mathrm{Li}_{2} \mathrm{O}\right)+0.0679$ 


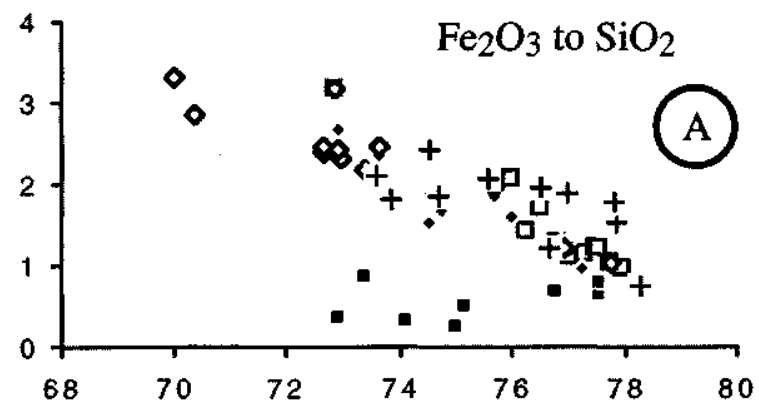

$\mathrm{SiO}_{2}, \%$

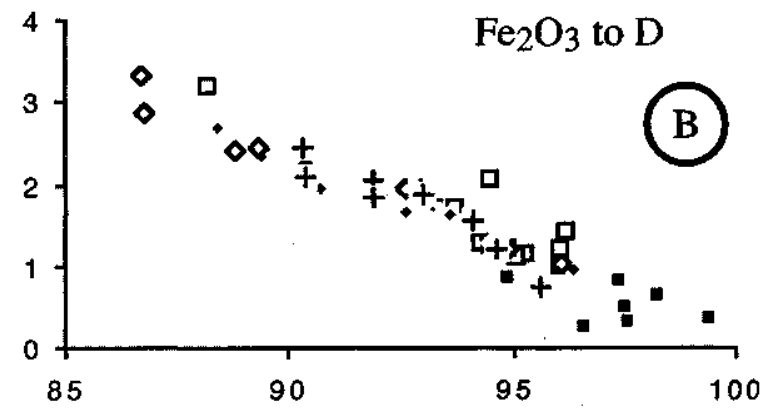

D
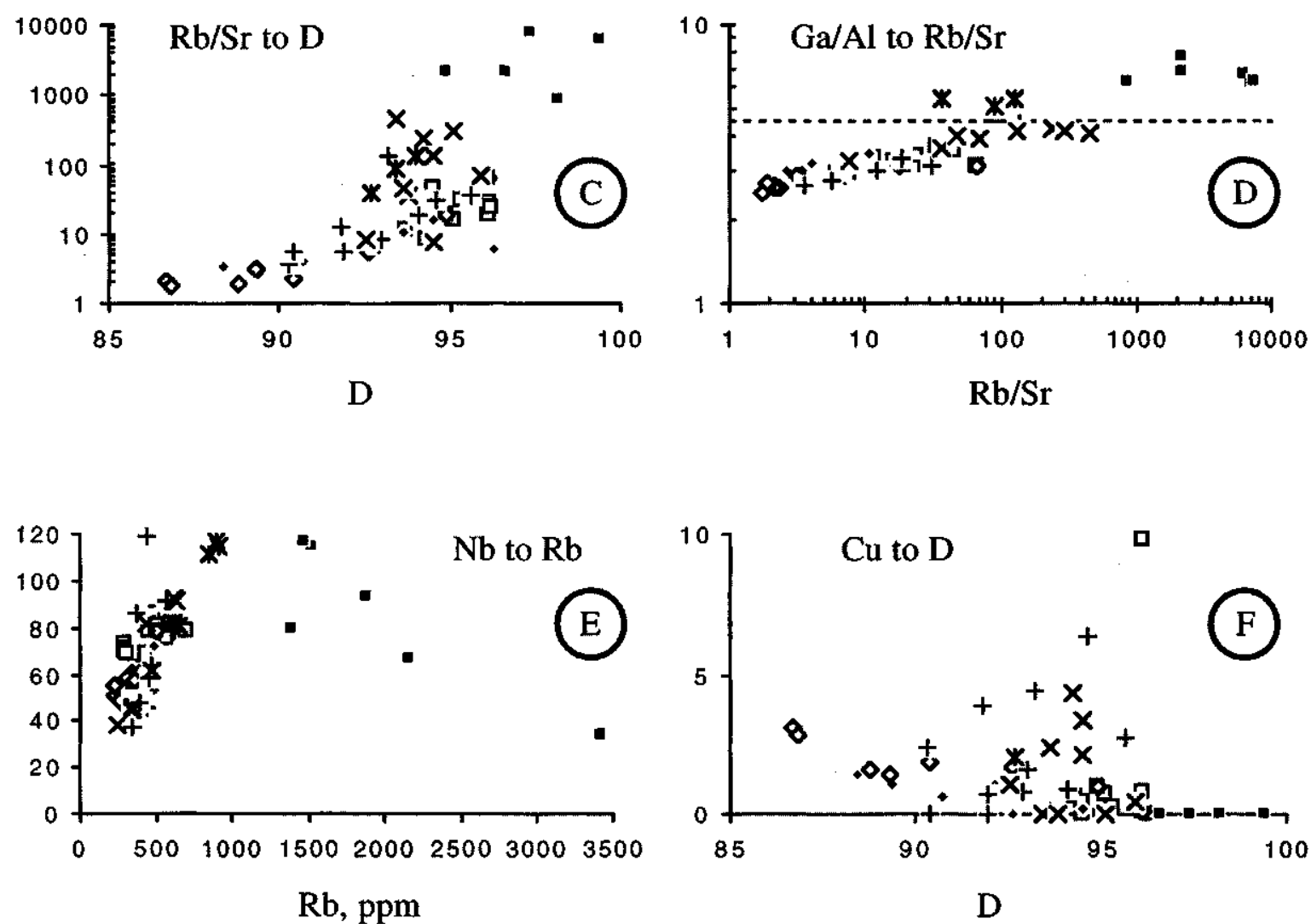

Figure 3 - Variation diagrams for the Seagull-Thirtymile granites: A. Total Fe as FeiOj plotted as a Marker diagram for Thitymile, Ork and Hake lithofacies. The Li-mica leucogranites appear to define a trend separate from the biotite granites, however the most evolved Li-mica granites are those to the left of the lower trend. B. Use of the Thornton-Tuttle differentiation index gives a simple evolutionary trend. $\boldsymbol{C}$. Rb/Sr ratios increase linearly in the Thirtymile and Hake lithofacies, but are somewhat irregular in the evolved Seagull, STQ and Li-mica fades. D. $\mathrm{Ga} / \mathrm{Al}$ is fractionated according to Rb/Sr. The STQ and Li-mica fades have values $>4.5$, normally associated with A-type plutons. $\mathrm{E}$. Nb is enriched withfractionation in the biotite granites, but diminishes in the Li-mica fades. This is interpreted to be the result of 'ultrafractionation', where efficient extraction of incompatible met als has removed them from late-formed fades. $\boldsymbol{F}$. Cu, present as a trace is erratically enriched in the evolved biotite-bearing fades.Symbols are: open diamonds = T.M. porphyry; filled diamonds - T.M. megacrystic; open squares = T.M. even-grained; filled squares $=$ T.M. \& Ork Li-mica; $+=$ Hake; $X=$ Seagull; and X with dash $=S T Q$.

The resulting diagram indicates that there is neither indication of the muscovite-lepidolite substitution series (as shown by Henderson et al. 1989) in the Seagull-Thirtymile micas, nor of the phengitezinnwaldite series reported by Moura \& Botelho (1994). Except for the more obviously $\mathrm{Fe}^{2+}$-rich composition of the micas from the least-evolved granites of this study (e.g. Fig. 10), these compositions compare well with Cornubian micas reported by Henderson et al. (1989).

Since Li contents were determined by ICP for all specimens of this study, there was no need to use an empirical relationship for estimation of $\mathrm{Li}_{2} \mathrm{O}$ content. The relation was, however, determined for the Seagull-Thirtymile micas giving:

$\mathrm{Li}_{2} \mathrm{O}=0.2397$ (SiCfc) - 8.1571 $\quad \mathrm{R}^{2}=0.9239$

which is quite similar to the equation given in Stone et al. (1988)

for the Cornubian $\mathrm{Li}$-Fe micas:

$\mathrm{Li}_{2} \mathrm{O}=0.236\left(\mathrm{SiO}_{2}\right)-7.56$

Other relationships reported are:

$\mathrm{Li} 2 \mathrm{O}=0.287\left(\mathrm{SiO}_{2}\right)$ - 9.552 -Tindle \& Webb (1990):

$\mathrm{Li}_{2} \mathrm{O}=0.215\left(\mathrm{SiO}_{2}\right)$ - 7.119 - Moura \& Botelho (1994): 
Table 1. Major (wt. \%) and selected trace element (ppm) compositions for some Thirtymil (TM) e and STQ stock specimens. These cover the full compositional range of the Seagull-Thirtymile suite.

\begin{tabular}{|c|c|c|c|c|}
\hline SPECIMEN: & HPG & $97 / 28-5$ & $97 / 26-3$ & STQ core \\
\hline FACIES: & TM / Porphyry & TM / Mega. & TM / Li-mica & STQ stock \\
\hline $\mathrm{SiO}_{2}$ & 72.99 & 74.57 & 77.54 & 77.16 \\
\hline $\mathrm{Al}_{2} \mathrm{O}_{3}$ & 13.64 & 13.32 & 12.94 & 12.52 \\
\hline $\mathrm{Fe}_{2} \mathrm{O}_{3} *$ & 2.32 & 1.55 & 0.80 & 1.39 \\
\hline $\mathrm{MgO}$ & 0.45 & 0.20 & 0.00 & 0.14 \\
\hline $\mathrm{CaO}$ & 1.30 & 0.94 & 0.04 & 0.50 \\
\hline $\mathrm{Na}_{r} \mathrm{O}$ & 3.55 & 3.67 & 4.62 & 3.22 \\
\hline $\mathrm{K}_{2} \mathrm{O}$ & 5.24 & 5.34 & 3.88 & 4.34 \\
\hline $\mathrm{TiO}_{2}$ & 0.39 & 0.22 & 0.01 & 0.06 \\
\hline Mnó & 0.05 & 0.04 & 0.05 & 0.01 \\
\hline $\mathrm{P}_{2} \mathrm{O}_{5}$ & 0.10 & 0.06 & 0.02 & 0.02 \\
\hline Total & 100.02 & 99.90 & 99.88 & 99.36 \\
\hline LOI & 0.49 & 0,33 & 0.34 & 0.59 \\
\hline Ba & 657 & 353 & 10 & 28 \\
\hline $\mathrm{Ga}$ & 19 & 22 & 43 & 36 \\
\hline $\mathrm{Sr}$ & 125.7 & 73.2 & 0.2 & 22.4 \\
\hline Rb & 234 & 483 & 1518 & 844 \\
\hline Nb & 52 & 53 & 115 & 111 \\
\hline Th & 45 & 50 & 24 & 88 \\
\hline Y & 39 & 34 & 9 & 157 \\
\hline $\mathrm{Zr}$ & 252 & 132 & 88 & 122 \\
\hline $\mathrm{Rb} / \mathrm{Sr}$ & 1.9 & 6.6 & 7588 & 37.7 \\
\hline $\mathrm{G} / \mathrm{A}]$ & 22.6 & 3.1 & 6.3 & 5.4 \\
\hline $\mathbf{K} / \mathbf{R b}$ & 185.9 & 91.8 & 21.2 & 42.7 \\
\hline $\mathrm{D}^{+}$ & 88.9 & 92.4 & 97.4 & 92.7 \\
\hline
\end{tabular}

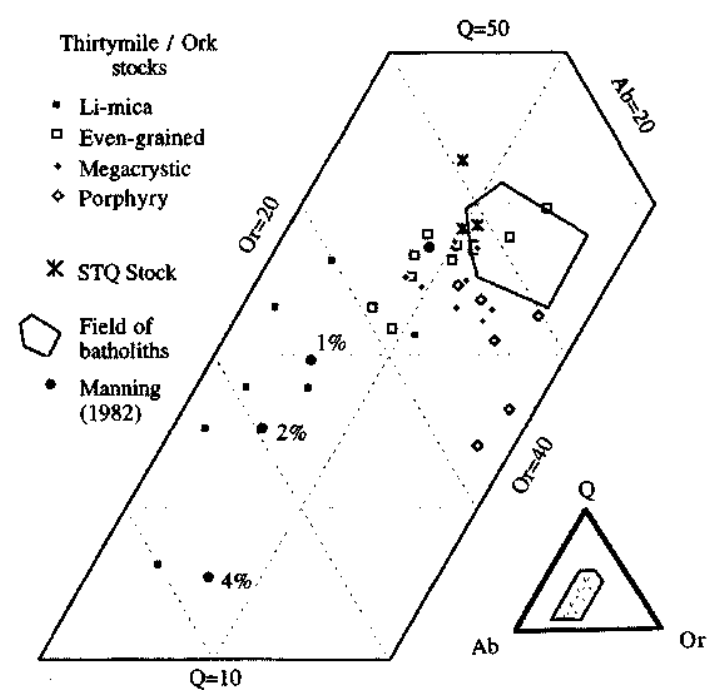

Figure 4. - C.I.P.W. normative quartz-albite-orthoclase components for the Seagull-Thirtymile granites. Shown also are the compositions of the liquidus minima for the system $Q$-Ab-Or with excess water at Ikbar with $0,1.2 \& 4 w t \% F$. There is a trend from porphyry as the most 'primitive'fades towards quartz enrichment in the even-grained fades of the Thirtymile Stock, with perhaps the extreme composition possible in the suite shown by the STQ alaskite. Also evident is the fluorine-rich trend towards albite crystallisation from even-grained fades to the Li-mica fades of the Ork and Thirtymile stocks.

CALCULATION OF RELATIVE HALOGEN FUGACITIES Relative fugacities of $\mathrm{HF} / \mathrm{HCl}$ have been calculated for the magmatic fluid equilibrating with the micas, using equations given in van Middelaar \& Keith (1990), based on the work of Munoz (1984). No means of estimating the final equilibration temperature was available (fluid inclusion studies have indicated a temperature range for fluid interaction with quartz of miarolitic cavities from $=550-150^{\circ} \mathrm{C}$ ), so calculation was performed using a value of $650^{\circ} \mathrm{C}$ to show trends. In a system such as that of the Seagull-Thirtymile intrusions granite melts enriched in $\mathrm{F}, \mathrm{Li}, \mathrm{Rb}, \mathrm{Cs}$, and $\mathrm{B}$ could actually exist down to $500-550^{\circ} \mathrm{C}$ at Ikbar (Henderson et al., 1989). Calculated values of $\log f_{\mathrm{HF}} / f_{\mathrm{HCL}}$ vary considerably according to temperature value used, but the gradient of contours shown on Fig. 10 does not, i.e. the sense of a trend in fugacities

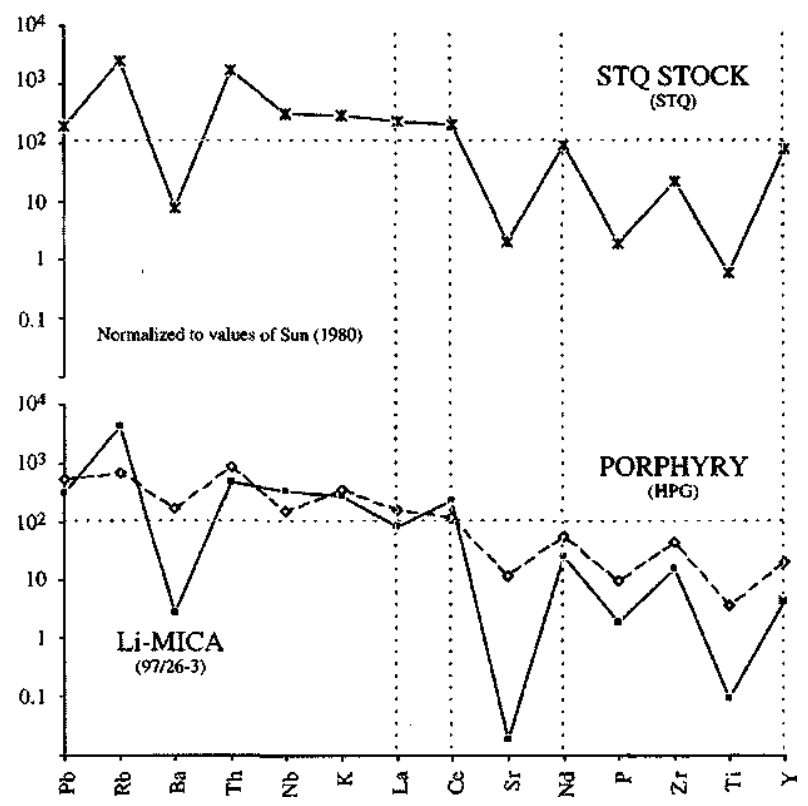

Figure 5 - 'Spidergrams' normalised to chondrite for the least- and most-fractionated examples from the Thirtymile and the Ork stocks, showing the range of negative $\mathrm{Ba}, \mathrm{Sr}$, and Ti anomalies. Note that only the porphyry shows some semblance of a negative $\mathrm{Nb}$ anomaly.

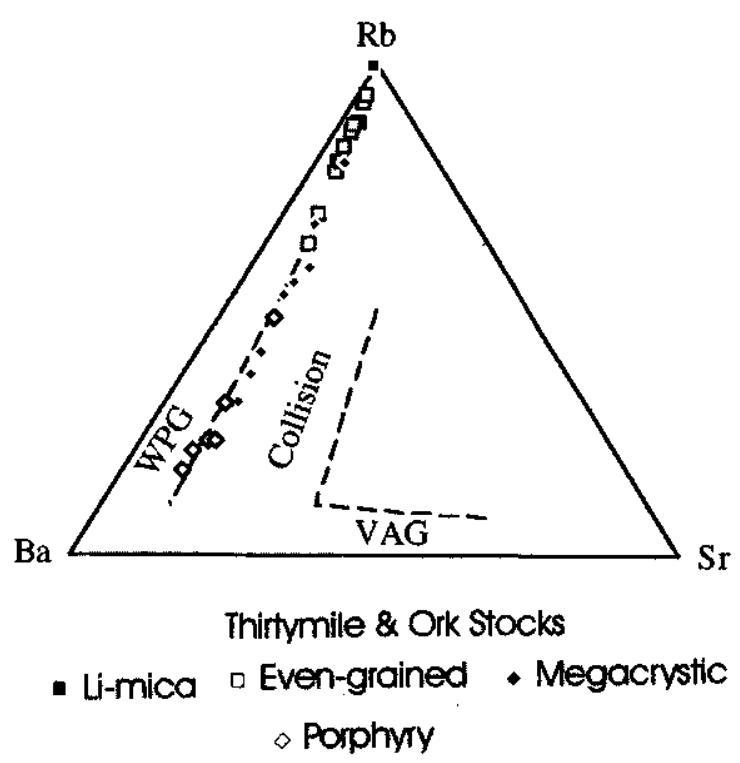

Figure 6 - The Rb-Ba-Sr ternary diagram for these granites demonstrates their extremely fractionated nature. They straddle the "WithinPlate "- "Collisional" field boundary.

is demonstrated by this diagram. A decreasing $\log f_{\mathrm{HF}} / f_{\mathrm{HCL}}$ trend with fractionation is demonstrated by the Seagull-Thirtymile granites. This contrasts with a nearly constant value for CanTung granites and skarns shown by van Middelaar \& Keith (1990).

DISCUSSION Tin Granites The requirements for formation of tin deposits were discussed by Plimer (1987). These are that the associated intrusion must be a late-stage of a post-kinematic granite. Such granite magmas must be initially low in water (in order to rise to a shallow crustal level without 'freezing'). Production of a solid 'carapace' around the intrusion and subsequent fracturing of this by hydraulic pressure as the crystallizing late-stage granitic melts exsolve water provides the hydrothermal system for mineralization as a succession of 'pulses'. 
Release of magmatic fluid (pressure) from shallow plutons allows partitioning of $\mathrm{Cl}$ into the aqueous fluid (Webster \& Holloway 1990), whilst $\mathrm{F}$ remains in the silicate melt, provided $\mathrm{F}<7 \%$. After $80-95 \%$ crystal-liquid fractionation of a pluton with early vapour loss 'ultrafractionation' can occur to enrich (incompatible) ore elements to significant grades (Newberry et al. 1990; Liverton \& Alderton 1994).

A further requirement for tin granites is that $f_{2}$ of the magma be low. If $\mathrm{Sn}$ is in the 4+ state it is capable of substitution into Ti-bearing minerals and thus would remain in crystallizing phases and not be available for concentration as an incompatible met al (Candela 1989).

The Seagull-Thirtymile Suite As Tin Granites The plutons of this study are reduced-type granites. Micas analyzed indicate that $\mathrm{fO}_{2}$ was mostly constrained below the NNO buffer in this suite (Fig. 11). The range of $f \mathrm{O}_{2}$ indicated qualitatively by this diagram shows these magmas to have been somewhat more reduced than the tin granites of the Erzegebirge (Forster \& Tischendorf 1992 indicate that the Younger series evolved from magmas with values above the NNO buffer).

Shallow depth of emplacement is indicated by miarolitic cavities and pod pegmatite in the Seagull and Thirtymile plutons. Fault channeling of hydrothermal fluids in the Thirtymile Range, adjacent to the Ork stock, is indicated by skarn distribution and visible alteration zones (Liverton 1992). Early release of magmatic fluid is likely to have occurred. The trend in decreasing $\log f_{\mathrm{HF}} / f_{\mathrm{Ha}}$ calculated for magmatic fluid (Fig. 10) is consistent with at least a periodic 'open-system' behavior, that would allow evolution of a Cl-Sn-rich hydrothermal fluid that contributed to known skarn Sn mineralization.

Granite Type The Seagull-Thirtymile granites are atypical of their region of the Cordillera, as are also the Tombstone suite. They are similar to 'post-orogenic-collisional' granites. They have alkaline-type chemistry (yet are not peralkaline), have high $\mathrm{Fe} / \mathrm{Mg}$ and are enriched in incompatible elements, are reduced and show $\mathrm{Sr}$ isotopic signatures indicating some crustal component to an I-type magma. Their time of
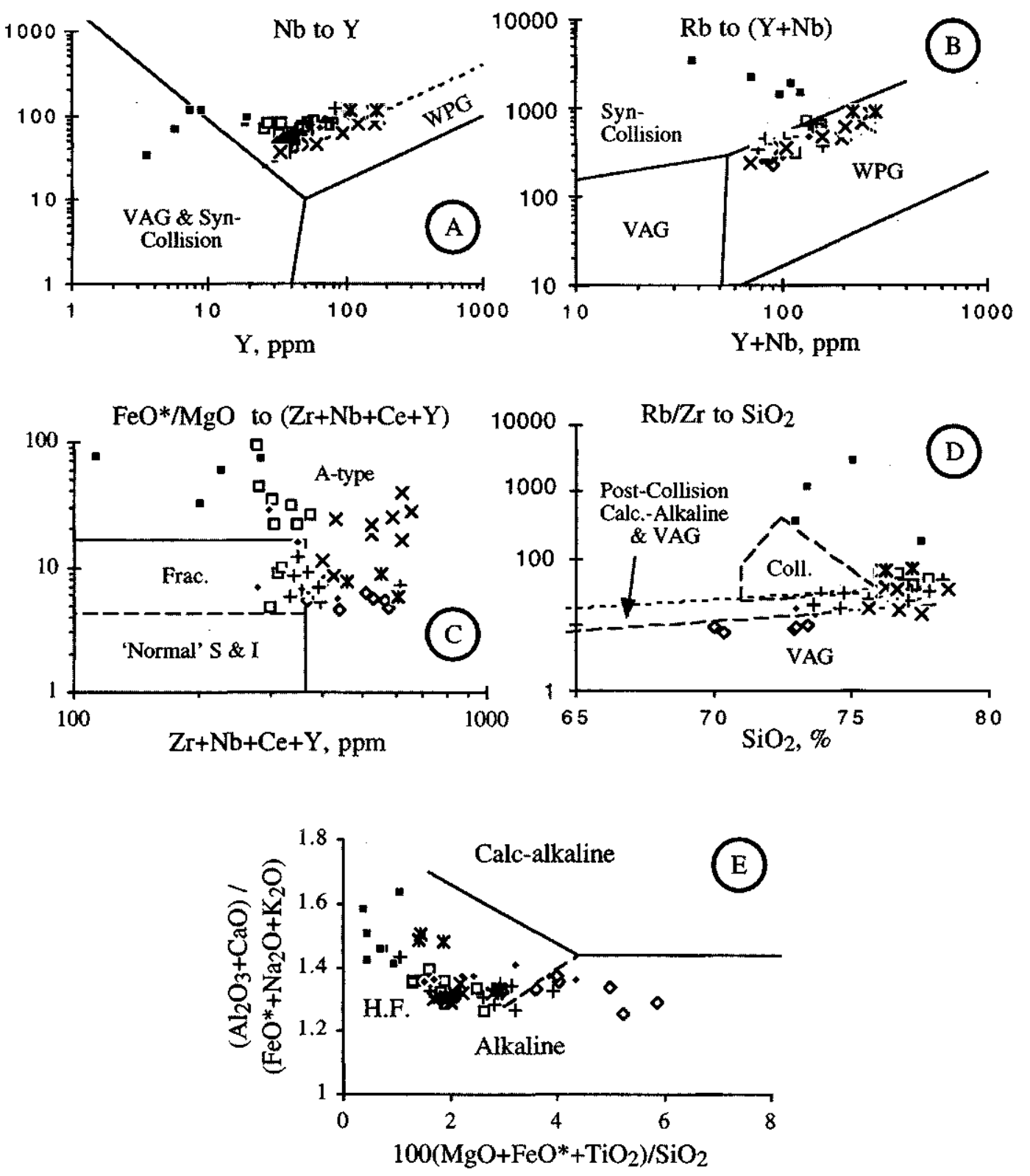

Figure 7 - The usual 'tectonic-discrimination' diagrams. $\boldsymbol{A} \&$ B. Pearce et al. (1987) trace element diagrams show the suite to fall mostly in the "Within-Plate"field, except some of the leucogranites. $\boldsymbol{C}$. The Whalenet al. (1987) diagram indicates an A-type signature for most of the granites, with the rest falling in the "Fractionated" field. D. On the Harris et al. (1986) diagram for collisional granites the Seagull-Thirtymile biotite fades fall in the "Collisional" to "Post-Collisional" fields. $\boldsymbol{E}$. On the Sylvester (1989) major element diagram these granites occupy the "Alkaline" field, with most being in the "Fractionated" part. 


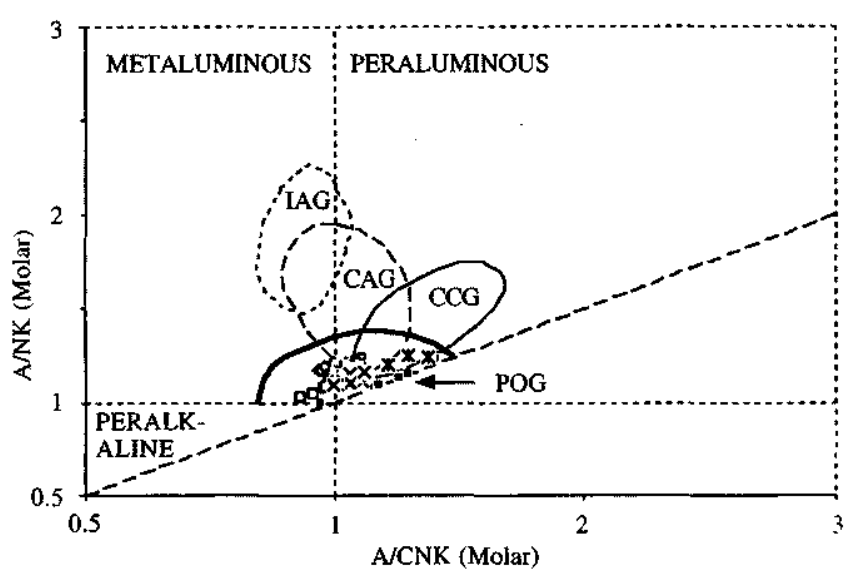

Figure 8 - Shand diagram with fields according to tectonic settings as defined by Maniar \& Piccoli (1989). The granites of this study occupy their "Post-Orogenic Granite" field.

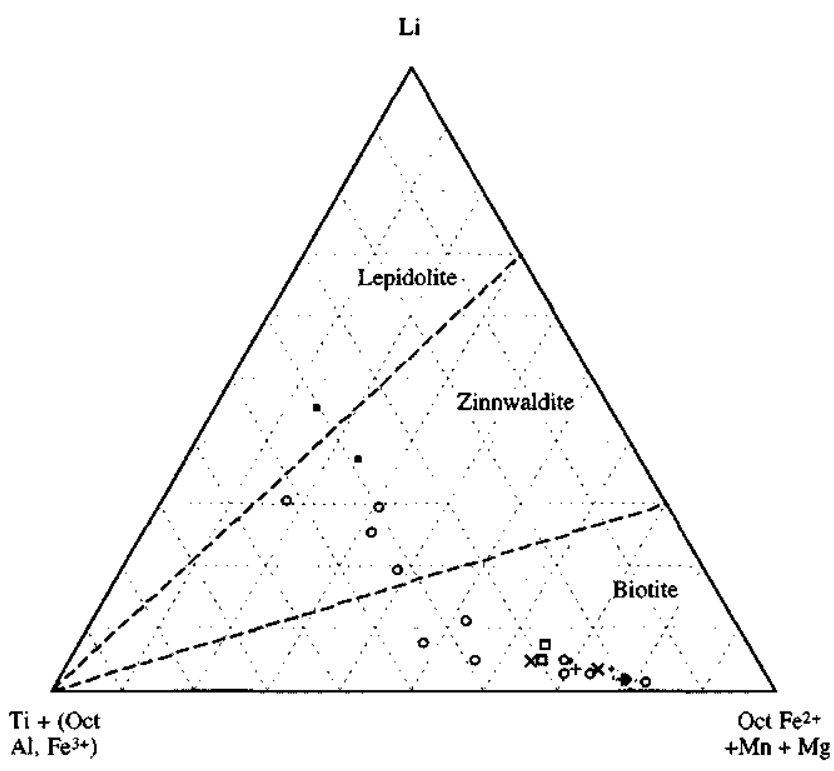

Figure 9 - Micas of the Seagull-Thirtymile granites plotted according to the modified parameters used by Tindle \& Webb (1990). Siderophyllite to Zinnwaldite are represented. The least fractioned granites contain biotites that are markedly more Fe-rich than those reported from Cornubia.Symbols as for Fig. 2, except for open circles which represent biotites from the T.M. even-grained fades, where some of $\mathrm{Rb}, \mathrm{F}$, or $\mathrm{H}_{2} \mathrm{O}^{+}$were estimated from empirically-derived formulae.

intrusion $(\approx 101 \mathrm{Ma}$ for the Thirtymile; $98 \mathrm{Ma}$ for the Hake (Liverton 1992 ) and $100 \mathrm{Ma}$ for the Seagull (Sinclair 1986) is not greatly different from that of the major batholiths in the region (Cassiar: one K-Ar date of $87 \mathrm{Ma}$ and three varying from 98 to $105 \mathrm{Ma}$; Marker: $\mathrm{K}-\mathrm{Ar}=126 \mathrm{Ma}$; Gabrielse et al. 1980), which were emplaced at the peak of metamorphism/plutonism in the Ominecabelt. The timing of intrusion does not follow some $20 \mathrm{Ma}$ after continent collision nor does it coincide with an obvious period of crustal thinning through extension. Existing tectonic models for the Cordillera consider the middle Cretaceous as a time of maximum crustal thickness in the Omineca belt. Major transcurrent faulting on the Tintina-Rocky Mountain system did not commence until the Eocene (J.K. Mortensen, pers. comm.), however the NW-SE linear trend of the Seagull-Thirtymile plutons does indicate the possibility that they were emplaced along a crustal-scale strike-slip

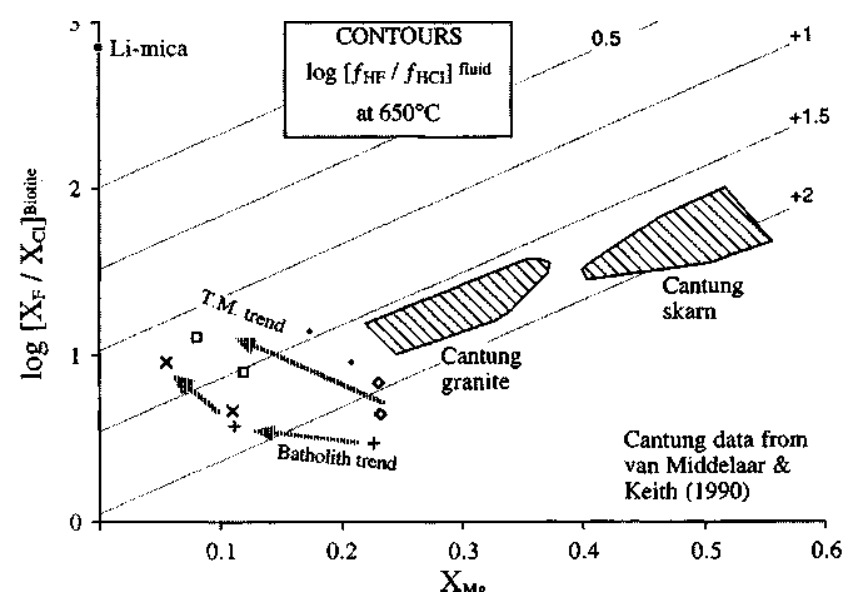

Figure 10 - Mica compositions are used to calculate relative HF and $\mathrm{HCl}$ fugadties that prevailed in the magmatic fluid. Temperature of equilibration between fluid and micas is unknown (and in such a $B-F-L i$-rich system melt may have persisted down to $550^{\circ} \mathrm{C}$ ), but whatever value is chosen for calculation the sense of the trend is unchanged. Unlike the relatively closed-system in the CanTung $W$ skarn system, where $\log f_{\mathrm{HF}} / f_{\mathrm{Ha}}$ is virtually unchanged, the system of this study indicates evolution of an increasingly Cl-rich fluid. This is consistent with release of early magmatic aqueous fluid, allowing 'idtrafractionation' during the 'second-boiling' process.

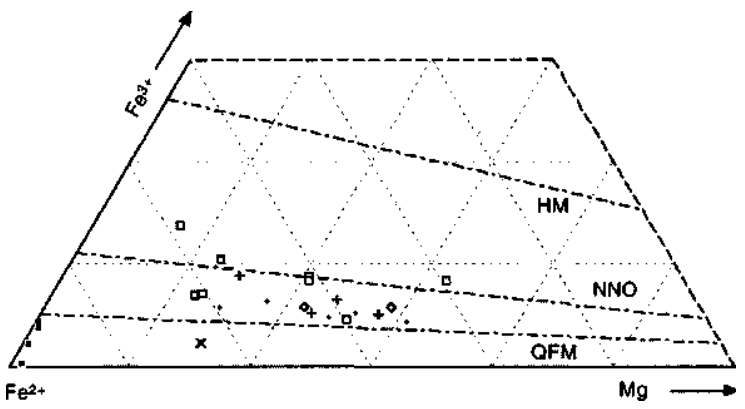

Figure 11 - Mica composition used to qualitatively estimate the conditions of fo2 in the Seagull-Thirtymile magmas. Most specimens indicate distinctly reduced type magma (Nickel-Nickel Oxide to Quartz-Fayalite-Magnetite), with the Seagull and Li-mica fades having the lowest range. Oxygen buffers from Wones \& Eugster (1965).

fault, but surface evidence for this is not obvious. It may simply be that the major structure controlling magma emplacement is an old lineament in the basement hidden beneath the displaced Dorsey terrane.

There has been much recent work on the genesis of A-type granites. Collins et al. (1982) proposed that melting of a felsic granulitic source (a restite) would form A-type magma. Skjerlie \& Johnston (1992) indicated that tonalitic gneiss, that they interpreted as being material depleted by an former melting event, could melt at pressures of lOkbar and temperatures of $>900^{\circ} \mathrm{C}$ to produce F-bearing melts similar to A-type granitoids, although their model was considered to be more appropriate to truly anorogenic (mantle plume-related) granite types by Rogers \& Satterfield (1993). Frost \& Frost (1997) also proposed remelting, but of tholeiitic underplate, as the likeliest source of the particularly reduced-type Rapakivi granites. Partial re-melting (15$40 \%$ ) of tonalite was suggested as a source by modelling presented by Greaser et al.(1991) and Haapala \& Rämö (1992) suggest 20\% melting of granodioritic material as the source of the Finnish A-type granites. Experimental work (Patino Douce 1997) indicates that magmas with the A-type chemical signature of the Seagull-Thirtymile might be 
generated at comparatively shallow depths ( $\mathrm{p} \approx 4 \mathrm{kbar}$ ) by remelting of calc-alkaline hornblende-biotite bearing granitoids, rather than by high-temperature restite melting in the lower crust. Such a process, requiring temperatures of $>900^{\circ} \mathrm{C}$, implies intrusion of basic magma into the middle crust. This alternative high-level source for 'alkaline', rather than neccessarily 'anorogenic' granites offers an intriguing alternative to the lower-crustal source. It is perhaps possible to postulate intrusion of basic magma to comparatively shallow levels during the last stage of major plutonism, when perhaps the thermal gradient in the lower and middle crust was elevated. Such a model might be tested once results of the Lithoprobe Project (Geological Survey of Canada) in this region become available.

CONCLUSIONS The Seagull-Thirtymile granite suite is distinct from most of the other Cretaceous granitoid batholiths in the northern Canadian Cordillera by virtue of its met allogeny (predominantly tin rather than tungsten) and its highly evolved chemical nature and Alkaline-type affinity. Even the least-evolved lithofacies (Thirtymile Porphyry) has indices of 'fractionation' such as $\mathrm{Rb} / \mathrm{Sr}=>1.7$ that are greater than most cordilleran plutons. Comparable intrusions are only found in the Tombstone Suite to the north, which is only slightly younger ( $\pm 93 \mathrm{Ma}$ for the whole $500 \mathrm{~km}$ long suite; Mortensen 1996).

Generation of alkaline-type granitoids immediately following major plutonism in a cordilleran setting, without either a spatial or time gap from calc-alkaline magmatism is somewhat unusual and at present unexplained.

Calculation of relative halogen fugacities for the magmatic aqueous fluids indicates that the hydrothermal systems of these reduced-type granites became progressively $\mathrm{Cl}$-rich, which is consistent with their being shallow, tin-related intrusions.

\section{References}

Anderson, J.L. (ed.) 1990. The nature and origin of Cordilleran magmatism. Geol. Soc. Amer. Memoir 174, $414 \mathrm{p}$

Barbarin, B. 1990. Granitoids: main petrogenetic classifications in relation to origin and tectonic setting. In M.P. Atherton and M.H. Naggar (eds.) Granite. Symposium celebrating the 70th birthday of W.S. Pitcher. Geol. Jour. 25;227-238.

Candela, P.A. 1989. Felsic magmas, volatiles, and met allogenesis. In J.A. Whitney and A.J. Naldrett, (eds.) Ore Deposition Associated with Magmas. Review in Economic Geology 4, p. 223-233.

Cobbing, E.J., Pitfield, P.E.J., Darbyshire, D.P.F., and Mallick, D.I.J. 1992. The granites of the South-East Asian tin belt. Brit. Geol. Survey, Overseas Memoir $10.366 \mathrm{p}$.

Collins, W.J.; Beams, S.D.; White, A.J.R.; Chappell, B.W. 1982. Nature and origin of A-type granites with particular reference to Southeastern Australia. Contrib. Mineral. Petrol., 80:89-200.

Creaser, R.A.; Price, R.C.; Wormald, R.J. 1991. A-type granites revisited: Assessment of a residual-source model. Geol., 19:163-166.

Forster, H.-J.\& Tischendorf, G. 1992. Volatile signatures of the Hercynian postkinematic granites of the Erzegebirge: Implications to related tin-tungsten-molybdenum met allogenesis. Chemie der Erde, 52:49-61.

Frost, C.D.\& Frost, B.R. 1997. Reduced rapakivi-type granites: The tholeiite connection. Geol., 25:647-650.

Gabrielse, H.; Tempelman-Kluit, D.J.; Blusson, S.L.; Campbell, R.B. (comps.) 1980. Macmillan River. Geol. Surv. Canada Map 1398A, Scale 1:1,000,000

Gordey, S.P. \& Stevens, R.A. 1994. Tectonic framework of the Teslin region, southern Yukon Territory. In: Current Research Part A. Geological Survey of Canada, Paper 1994-Ap. 11-18.

Haapala, I. \& Ramo, O.T. 1992. Tectonic setting and origin of the Proterozoic rapakivi granites of southeastern Fennoscandia. Transact. Royal Soc. Edinburgh, Earth Sciences, 83:165-171

Hall, A. \& Walsh, J.N. 1969. A rapid method for the determination of fluorine in silicate rocks. Anal. Chim. Acta, 45:341-342.

Harris, N.B.W.; Pearce, J.A.; Tindle, A.G. 1986. Geochemical characteristics of collision-zone magmatism. In M.P. Coward, and A.C. Ries, (eds.) Collision Tectonics. Geological Society of London Special Publication 19, p.67-81.

Henderson, C.M.B.; Martin, J.S.; Mason, R.A. 1989. Compositional relations in Li-micas from S.W. England and France: an ion- and electron- microprobe study. Mineral. Mag. 53:427-449.

Layne, G.D.\& Spooner, E.T.C. 1986. The JC Sn-Fe-F skarn Seagull Batholith area, southern Yukon. In J. Morin, (ed.): Mineral deposits of the Northern Cordillera. Canadian Institute of Mining, Met allurgy and Petroleum Special Vol. 37, p. 266-273.

Layne, G.D.\& Spooner, E.T.C. 1991. The JC tin skarn deposit, southern Yukon Territory: I. Geology, paragenesis, and fluid inclusion microthermometry. Earn. Geol., 86:29-47.

Liverton, T. 1992. Tectonics and met allogeny of the Thirtymile Range, Yukon Territory, Canada. Royal Holloway, University of London. Ph.D. thesis, 315p.

Liverton, T. \& Alderton, D.H.M. 1994. Plutonic rocks of the Thirtymile Range, Dorsey Terrane: ultrafractionated tin granites in the Yukon. Can. Jour. Earth Sci., 31:1557-1568.

Maniar, P.O. \& Piccoli, P.M. 1989. Tectonic discrimination of granitoids. Bull. Geol. Soc. Amer.: 101:635-643.

Manning, D.A.C. 1982. An experimental study of the effects of fluorine on the crystallisation of granitic melts. In: Evans.A.M. (ed.) Met allization associated with acid magmatism. Wiley, Chichester. p. 191-203.

Mato, G.; Ditson, G.; Godwin, C. 1983. Geology and geochronometry of tin mineralization associated with the Seagull Batholith, south-central Yukon Territory. Can. Inst. Mining, Met all. Petrol. Bull. 76:43-49.
Middelaar, W. Van \& Keith, J.D. 1990. Mica chemistry as an indicator of oxygen and halogen fugacities in the CanTung and other W-related granitoids in the North American Cordillera. In H.J. Stein, and J.L. Hannah, (eds.) Ore-bearing granite systems; petrogenesis and mineralizing processes. Geological Society of America Special Paper 246, p. 205-221.

Mortensen, J.K. 1996. Intrusion-related gold and base met al mineralization associated with the early Cretaceous Tombstone plutonic suite, Yukon and east-central Alaska. In notes for the short course. New Mineral Deposit Models of the Cordillera. British Columbia Geological Survey, The University of British Columbia and Geological Survey of Canada, p. LI-13.

Moura, M.A. \& Botelho, N.F. 1994. Estudo de micas litinlferas e sua importância para a caracterizacao das rochas da zona greisenizada principal do macico estanffero Mangabeira, GO. Bol. Geoc. do Centro-Oeste, 17:39-48.

Munoz, J.L. 1984. F-OH and Cl-OH exchange in micas with applications to hydrothermal ore deposits. In S.W. Bailey, (ed.) Micas. Mineralogical Society of America Reviews in Mineralogy 13:469-493.

Newberry, R.J.; Burns, L.E.; Swanson, S.E.; Smith, T.E. 1990. Comparative petrologic evolution of the $\mathrm{Sn}$ and $\mathrm{W}$ granites of the Fairbanks-Circle area, interior Alaska. In H.J. Stein, and J.L. Hannah, (eds.) Ore-bearing granite systems; petrogenesis and mineralizing processes. Geological Society of America Special Paper 246, p. 121-142.

Patino Douce, A.E. 1997. Generation of met aluminous A-type granites by low-pressure melting of calc-alkaline granitoids. Geol., 25:743-746.

Pearce, J.A.; Harris, N.B.W.; Tindle, A.G. 1984. Trace element discrimination diagrams for the tectonic interpretation of granitic rocks. Jour. Petrol., 25:956-983.

Plant, J.A.; O'Brien, C.; Hurdley, J. 1985. Geochemical criteria for the recognition of high heat production granites. In: High heat production (HHP) granites, hydrothermal circulation and ore genesis. Inst. Min. Met all. Lond., p. 263-285.

Plimer, I.R. 1987. Fundamental parameters for the formation of granite-related tin deposits. Geolog. Rund. 76/1:23-40

Rogers, J.J.W. \& Satterfield, M.E. 1993. Vapor-absent melting at $10 \mathrm{kbar}$ of a biotite- and amphibole-bearing tonalitic gneiss: implications for the generation of A-type granites: Comment. Geol., 21:89.

Skjerlie, K.P. \& Johnston, A.D. 1992. Vapor-absent melting at $10 \mathrm{kbar}$ of a biotite- and amphibole-bearing tonalitic gneiss: implications for the generation of A-type granites. Geol., 20:263-266.

Stone, M.; Exley, C.S.; George, M.C. 1988. Compositions of trioctahedral micas in the Cornubian batholith. Mineral. Mag., 52:175-192

Sylvester, P.L. 1989. Post-collisional alkaline granites. Jour.Geol., 97:261-280.

Tindle, A.G. \& Webb, P.C. 1990. Estimation of lithium contents in trioctahedral micas using microprobe data: application to micas from granitic rocks. Europ. Jour Mineral, 2:595-610.

Webster, J.D. \& Holloway, J.R. 1990. Partitioning of F and CI between magmatic hydrothermal fluids and highly evolved granitic magmas. In H.J. Stein, and J.L. Hannah, (eds.) Ore-bearing granite systems; petrogenesis and mineralizing processes. Geological Society of America Special Paper 246, p. 21-34.

Whalen, J.B.; Currie.K.L.; Chappell, B.W. 1987. A-type granites: geochemical characteristics, discrimination, and petrogenesis. Contrib. Mineral. Petrol. 95:407-419.

Wones, D.R. \& Eugster, H.P. 1965. Stability of biotite: Experiment, theory, and application. Amer. Mineral., 50:1228-1272. 